\title{
The very low genetic variability on Aceh Tamiang's (Indonesia) population of Painted Terrapin (Batagur borneoensis) inferred by cytochrome oxidase I (CO I) and D-loop (control region)
}

\author{
JOKO GUNTORO ${ }^{1}$, WIRDATETI ${ }^{2, \vartheta}$, AWAL RIYANTO ${ }^{2, v \vartheta}$ \\ ${ }^{1}$ Satucita Lestari Indonesia. Jl. Perjuangan, Sidodadi Village, Kejuruan Muda Sub-district, Aceh Tamiang District, Aceh, Indonesia \\ ${ }^{2}$ Museum Zoologicum Bogoriense, Research Center for Biology, Indonesian Institute of Sciences, Widyasatwaloka Building. Jl. Raya Jakarta Bogor Km. \\ 46, Cibinong, Bogor 16911, West Java, Indonesia. Tel.: +62-21-876 5056, ”email: wirdateti@yahoo.com, ``awal_lizards@yahoo.com
}

Manuscript received: 6 March 2020. Revision accepted: 14 May 2020.

\begin{abstract}
Guntoro J, Wirdateti, Riyanto A. 2020. The very low genetic variability on Aceh Tamiang's (Indonesia) population of Painted Terrapin (Batagur borneoensis) inferred by cytochrome oxidase I (CO I) and D-loop (control region). Biodiversitas 21: $2514-2520$. Populations of Batagur borneoensis have been rapidly decreasing due to the harvesting of adults and eggs for food and the construction of beachfront property causing the loss of nesting areas. By the new Indonesian regulation, since 2018 this turtle listed in the protected animal. Meanwhile, IUCN placed as critically endangered which indicating a high risk of extinction in the wild in the near future (www.iucnredlist.org). We used cytochrome oxidase I (COI) and control region D-loop region to investigate intraspecific variations on Aceh Tamiang's population of painted terrapin, Batagur borneoensis. DNA material was gathered from saliva collected from 90 juveniles in the reaching facility of Sukacita Lestari Indonesia Foundation which hatched from eggs collected from December 2015 to April 2016 from 30 nests on beach area at Aceh Tamiang. The population showed very low genetic variability (haplotype diversity, Hd $=0.457$ based on COI and 0.405 based on D-loop; nucleotide diversity, $\pi=0.00089$ based on COI and 0.00076 based on $D$-loop). So, we suggested that further study such as more exploration to find new wild populations and genetic study across wild populations should be done to reveal genetic variability and genetic structure which important to decide the conservation strategy. At the time for Aceh Tamiang's population, the ranching conservation program should be maintained at least to keep the successful hatchling from hunters and natural predators both during eggs laying and hatching.
\end{abstract}

Keywords: Aceh Tamiang, Batagur borneoensis, COI, D-loop, genetic variability, Indonesia

\section{INTRODUCTION}

Turtles particularly have value to humans, whether as food, medicine, pets, or as providers of ecological services, and their very slow recovery from (over) exploitation, turtles tend to be at the cutting edge of biodiversity decline, and an indicator of ecosystem degradation. The turtles distribution and their occurrence of deep phylogenetic lineages, is not uniform across the planet. Therefore, turtles clearly represent a global biodiversity conservation priority (Mittermeier et al. 2015). Mittermeier et al. (2015) also placed Indonesia in the turtle priority area of Sundaland hotspot based on species richness and endemicity.

Painted terrapin (Batagur borneoensis) is one the nonmarine Indonesian turtle which listed critically endangered (IUCN 2017) and listed in 25 most extinction in the wold (Rhodin et al. 2011; Stanford et al. 2018). At the time, including in protected animals in Indonesia by Permenhut $106 / 2018$. Populations of this turtle have been rapidly decreasing due to the harvesting of adults and eggs for food and the construction of beachfront property causing the loss of nesting areas (Stanford et al. 2018). Duli (2009) showed that no genetic differentiation between south and north Peninsular Malaysia population and until now nothing known on the dispersal pattern of this terrapin. Believed, that now to be restricted to small remnant populations in
Malaysia and part of North Sumatra (Stanford et al. 2018). As a result of this population decline, B. borneoensis is listed by the IUCN as critically endangered, indicating a high risk of extinction in the wild in the near future (www.iucnredlist.org).

Aceh Tamiang beach is one of few known nesting areas of Batagur borneoensis in Indonesia (Guntoro 2012). Genetic variability is important that determine the availability or adaptation of the population from the environment changes (Moll and Moll 2004). In the small and limited population is believed to have low genetic variability. So, it is not excessive if information on the genetic variability of Aceh Tamiang's population is urgent to be known, especially as consideration in conservation efforts.

The use of genetics to inform evidence-based management decisions for highly threatened species can improve conservation outcomes (Allendorf et al. 2010; Zhan et al. 2014; Corlett 2016; Ismail et al. 2016; Pierson et al. 2016; Alvarez et al. 2019). Almost half of freshwater turtle species worldwide are threatened, and many exhibit low levels of genetic variability, therefore the identification of genetic within natural populations is important for conservation strategies (Ihlow et al. 2014). Mitochondrial DNA (mtDNA) and its loci are one of several approaches in genetic evaluation of wild animals, including in turtle 
studies (Lalitha and Chandavar 2018). For example, over the past several decades, genetics have helped answer an increasing diversity of research questions in marine turtle biology and conservation. Rapidly expanding genetic and genomic toolboxes will undoubtedly continue to expand knowledge in coming years. By collaborating and integrating these innovations with those in complementary disciplines, marine turtle conservation biologists can leverage these tools to tackle the remaining and emerging challenges in marine turtle ecology, evolution, and conservation management (Komoroske et al. 2017).

D-loop is the predominant regulatory most variable region of mtDNA, used to identify genetically discrete populations, foraging ground, and nesting behavior of turtles, intraspecific variability, and phylogenetic relationship (Nezhad et al. 2013). Meanwhile, COI is regarded as valuable molecular marker in turtle species studies (Bhaskar and Mohindra 2018).

Our work focused on intraspecific variations in COI and D-loop regions, which would be cumulative to the existing knowledge and growing database of mitogenome. This provides an imperative groundwork for future conservation studies on B. borneoensis species from Aceh Tamiang, Indonesia.

\section{MATERIALS AND METHODS}

\section{Study area}

The juveniles in the ranching facility of Sukacita Lestari Indonesia Foundation were hatched from eggs collected from 30 nests at riverbank in Ujung Aceh Tamiang, Aceh, Indonesia (N 0425'12.29”, E 098 16'49.35") December 2015 to April 2016 (Figure 1).

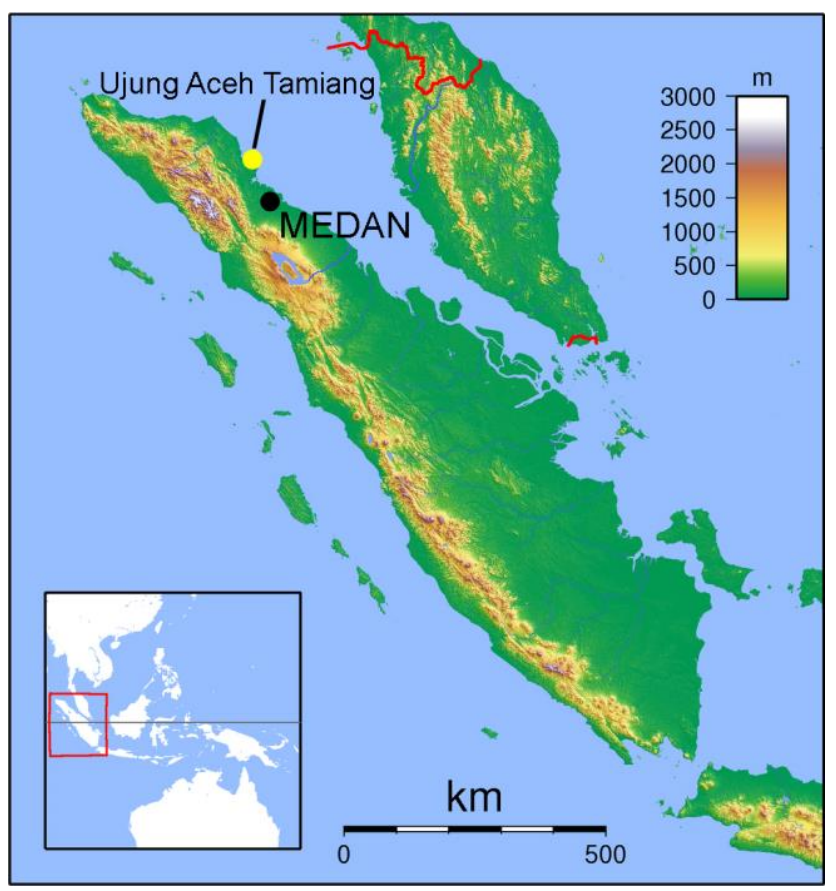

Figure 1. Map of Sumatra showing nest locality of eggs collected (yellow circle), Ujung Aceh Tamiang, Aceh, Indonesia

\section{Biometric data}

We measured each individuals juvenile before collected the buccal cells for DNA material sample. Measurement including stright median carapace length and stright maximum carapace width. We also recorded body weight.

\section{DNA material sampling}

DNA material gathered from buccal cells collected from 90 juveniles in the raching facility from 30 nests of Sukacita Lestari Indonesia with origin mentioned above in study area. The collected samples as many as three animals of each nest by random. The buccal cells preserved in $95 \%$ ethanol prior to extraction.

\section{DNA extraction and amplification}

Genomic DNA was extracted from saliva using a commercial Qiagen DNeasy Tissue Kit Kit, following the manufacturer's instructions. We amplified the D-loop region and $\mathrm{COI}$ gene mtDNA by polymerase chain reaction (PCR). The primer Bb d1F (5- TCTCTACATGACTTCA CAGAGGAT-3) and Bb_dlR (5-TGTTGCTTTAACGG GGGTAG-3) using for D-loop (Hawkins 2010), and COI Tuntong F (5-CGCGGAATTAAGCCAACCAG-3), and COI Tuntong R (5-TTGGTACAGGATTGGGTCGC-3) for COI was designed. PCR amplifications were done with reaction mixture from KAPA Robust HotStart (KAPA Biosystems product) in $30 \mathrm{ul}$. Thermal cycling follows: (i) D-loop predenaturation at $95^{\circ} \mathrm{C}$ for 10 minutes, 35 denaturation cycles at $94^{\circ} \mathrm{C}$ for 30 seconds, annealing at $57^{\circ} \mathrm{C}$ for 20 seconds, extension at $72^{\circ} \mathrm{C}$ for 5 minutes, and final extension at $72^{\circ} \mathrm{C}$ for 10 seconds; (ii) COI predenaturation $94{ }^{\circ} \mathrm{C}$ for 4 minutes, 35 denaturation cycles at $94^{\circ} \mathrm{C}$ for 45 seconds, annealing at $55^{\circ} \mathrm{C}$ for 35 seconds, extension at $72^{\circ} \mathrm{C}$ for 1 minute, followed by a final extension at $72^{\circ} \mathrm{C}$ for 10 minutes. Amplification was done used Biorad Thermo Cycler. PCR product was sequenced in First Base Co., Singapore, and Macrogen Co., Korea.

\section{Data analysis \\ Biometric}

We examined the body sizes and weight of 90 juveniles which hatched from 30 nests by using One-way ANOVA. The calculation was conduct by Minitab.

\section{Molecular}

The acquired sequences were edited using BioEdit software (Hall, 1999) and aligned using Clustal X (Thompson et al. 1994). For the haplotypes, we used DNaSP ver.5 (Librado and Rozas, 2009) to calculate haplotype diversity (h), Tajima's test, Fu and Li's test, and nucleotide diversity $(\pi)$. Haplotype diversity can be interpreted as the probability that two individuals from a given sampling unit will have different haplotypes. The Kimura 2-parameter genetic distance (d) measure (Kimura 1980) was calculated to reveal the genetic diversity in population in MEGA-X (Kumar et al. 2018).

We calculated the genetic distance between all pairwise comparisons of wild-caught 90 individuals of 30 nestings. Relationships among mitochondrial haplotypes were 
visualized by constructing a neighbor-joining tree and Maximum Likelihood using MEGA-X (Kumar et al. 2018). Branch points were tested with 5000 bootstraps using Kimura-2 parameter method.

\section{RESULTS AND DISCUSSION}

\section{Morphometric and weight}

The descriptive on carapace length, carapace width, and the weight of sample from each nest are presented in Table 1 . These were no significant $(\mathrm{p}=1.000)$ differences between 90 juveniles which hatched from 30 nests.

\section{Genetic variability}

Both of genetic marker COI and D-loop showed the Aceh Tamiang's population has very low genetic variability, is showing the lower genetic distance (d) of 90 juveniles from 30 nesting that was $0.001 \pm 0.001$; and between haplotype was $0.003 \pm 0.001$ (Table 2).

\section{COI}

The total number of the sequence length is $548 \mathrm{bp}$, and it found as many as 7 gaps in this alignment, so total number to analysis was $541 \mathrm{bp}$. The result of 90 individuals showing that number of variable sites $(\mathrm{S})$ is $6(1.12 \%)$, and sequence conservation (C) is 535 (98.89\%). The haplotype diversity, $\mathrm{Hd}=0.457 \pm 0.037$, this is indicated by a very low nucleotide variation that there are only 2 different sites in position 1 and to 2, i.e. base substitution from $\mathrm{A}$ to $\mathrm{C}$ or transversion. As a result, it's revealing three distinct haplotypes, e.i. AA (29 individuals), CA (60 individuals), and AC (1 individual) (Table 3). Several sites insertion and deletion but not change the protein composition. The nucleotide diversity, $\pi=0.00089 \pm 0.00008$ with average number of nucleotide differences, $\mathrm{k}=0.4717$.

\section{D-loop region}

From augmented 578 bp of D-loop region that was extracted from 90 individuals revealed four distinct haplotypes from three number of variable sites $(S=0.52 \%)$ at position 412,482 , and 575 , and sequence conservation (C) is $99.48 \%$ (575 sites). With only 22 individuals have different nucleotides with single base e.i. A to $G, G$ to $A$ and $\mathrm{A}$ to $\mathrm{T}$. The haplotype diversity, $\mathrm{Hd}=0.405 \pm 0.058$, it is revealing four haplotypes that are AGA (68 individuals); GGA (14 individuals); AGT (4 individuals); and AAA (4 individuals) (Table 3 ). The nucleotide diversity, $\pi=$ $0.00076 \pm 0.00012$ with average of nucleotide differences, $\mathrm{k}=0.4374$.

Table 1. Recorded on range body sizes and weights and it's mean \pm standard deviation (SD) of juvenile's Batagur borneoensis from 30 nests in Aceh's Tamiang nest area, Indonesia

\begin{tabular}{|c|c|c|c|c|}
\hline Nest & No. individuals & Weight & Median carapace length & Maximum carapace width \\
\hline 1 & 3 & $155-250(198.3 \pm 48.04)$ & $9.4-10.8(10.1 \pm 0.70)$ & $8.7-9.7(9.2 \pm 0.50)$ \\
\hline 2 & 3 & $155-195(170.0 \pm 21.80)$ & $9.7-10.1(9.83 \pm 0.23)$ & $8.8-9.4(9.0 \pm 0.32)$ \\
\hline 3 & 3 & $190-240(211.7 \pm 25.66)$ & $10.2-11.1(10.6 \pm 0.45)$ & $9.2-9.8(9.5 \pm 0.30)$ \\
\hline 4 & 3 & $200-275(230.0 \pm 39.67)$ & $10.4-11.8(10.9 \pm 0.81)$ & $9.4-10.4(9.73 \pm 0.58)$ \\
\hline 5 & 3 & $175-200(19.00 \pm 13.23)$ & $9.8-10.4(10.1 \pm 0.31)$ & $8.9-9.2(9.1 \pm 0.17)$ \\
\hline 6 & 3 & $175-200(185.0 \pm 13.23)$ & $10-20.7(13.7 \pm 6.09)$ & $9.3-9.8(9.5 \pm 0.27)$ \\
\hline 7 & 3 & $160-190(173.3 \pm 15.28)$ & $9.6-10.5(10.0 \pm 0.45)$ & $8.9-9.4(9.2 \pm 0.29)$ \\
\hline 8 & 3 & $150-155(151.7 \pm 2.89)$ & $9.3-9.4(9.4 \pm 0.06)$ & $8.6-8.8(8.7 \pm 0.1)$ \\
\hline 9 & 3 & $150-190(166.7 \pm 20.82)$ & $9.3-10(9.6 \pm 0.38)$ & $8.6-9.1(8.8 \pm 0.25)$ \\
\hline 10 & 3 & $170-190(176.7 \pm 11.55)$ & $9.6-9.9(9.8 \pm 0.15)$ & $8.8-9.8(9.2 \pm 0.56)$ \\
\hline 11 & 3 & $130-170(155.0 \pm 21.79)$ & $8.9-9.7(9.4 \pm 0.46)$ & $8.6-9.1(8.8 \pm 0.25)$ \\
\hline 12 & 3 & $180-190(185.0 \pm 5.00)$ & $9.9-10.3(10.1 \pm 0.21)$ & $9-9.3(9.1 \pm 0.17)$ \\
\hline 13 & 3 & $160-200(176.7 \pm 20.82)$ & $9.7-10.7(10.1 \pm 0.55)$ & $8.6-9.6(9.1 \pm 0.50)$ \\
\hline 14 & 3 & $160-190(180.0 \pm 17.32)$ & $9.3-10.2(9.90 \pm 0.52)$ & $8.5-9.2(8.9 \pm 0.38)$ \\
\hline 15 & 3 & $150-180(160.0 \pm 17.32)$ & $9.2-10.2(9.5 \pm 0.58)$ & $8-9.2(8.6 \pm 0.60)$ \\
\hline 16 & 3 & $160-180(170.0 \pm 10.00)$ & $9.7-9.8(9.8 \pm 0.06)$ & $8.8-9.0(8.9 \pm 0.12)$ \\
\hline 17 & 3 & $140-170(156.7 \pm 15.28)$ & $9.7-10(9.8 \pm 0.15)$ & $8.2-9.1(8.7 \pm 0.46)$ \\
\hline 18 & 3 & $150-190(173.3 \pm 20.82)$ & $9.1-10.2(9.8 \pm 0.64)$ & $8.6-9.8(9.2 \pm 0.60)$ \\
\hline 19 & 3 & $140-160(150.0 \pm 10.00)$ & $9.2-9.7(9.5 \pm 0.25)$ & $83-8.9(8.6 \pm 0.31)$ \\
\hline 20 & 3 & $150-180(163.3 \pm 15.28)$ & $9.5-10.2(9.7 \pm 0.40)$ & $8.9-9.1(9.0 \pm 0.10)$ \\
\hline 21 & 3 & $130-160(143.3 \pm 15.28)$ & $9-9.5(9.2 \pm 0.27)$ & $8.3-8.5(8.4 \pm 0.10)$ \\
\hline 22 & 3 & $120-150(140.0 \pm 17.32)$ & $9.2-9.7(9.4 \pm 0.27)$ & $8.5-8.8(8.6 \pm 0.15)$ \\
\hline 23 & 3 & $160-190(173.3 \pm 15.28)$ & $9.4-10.3(9.8 \pm 0.45)$ & $8.7-9.3(9.0 \pm 0.30)$ \\
\hline 24 & 3 & $140-150(143.3 \pm 5.77)$ & $9.2-9.5(9.4 \pm 0.15)$ & $8.2-8.7(8.4 \pm 0.25)$ \\
\hline 25 & 3 & $130-140(133.3 \pm 5.77)$ & $9.2-9.7(9 . .4 \pm 0.36)$ & $8-8.7(8.4 \pm 0.36)$ \\
\hline 26 & 3 & $140-160(146.7 \pm 11.55)$ & $9.2-9.8(9.5 \pm 0.31)$ & $8.4-8.7(8.6 \pm 0.15)$ \\
\hline 27 & 3 & $120-160(136.7 \pm 20.82)$ & $8.7-9.7(9.1 \pm 0.53)$ & $8.1-8.6(8.3 \pm 0.30)$ \\
\hline 28 & 3 & $120-150(133.3 \pm 15.28)$ & $8.8-9.4(9.2 \pm 0.32)$ & $8.1-8.7(8.5 \pm 0.35)$ \\
\hline 29 & 3 & 150 & $9.2-9.5(9.3 \pm 0.15)$ & $8.5-8.7(8.6 \pm 0.10)$ \\
\hline 30 & 3 & $100-140(123.3 \pm 20.82)$ & $8.4-9.5(9.0 \pm 0.57)$ & $7.6-8.4(8.1 \pm 0.44)$ \\
\hline \multicolumn{2}{|r|}{ Overall } & $100-271(164.9 \pm 20.57)$ & $8.4-20.7(9.8 \pm 1.28)$ & $7.6-10.4(8.9 \pm 0.48)$ \\
\hline
\end{tabular}


Table 2. The polymorphism data on COI and D-loop of Batagur borneoensis in Ujung Aceh Tamiang's population (Aceh, Indonesia)

\begin{tabular}{cccccc}
\hline mtDNA Markers & Distance (d) & $\begin{array}{c}\text { Haplotype } \\
\text { diversity (Hd) }\end{array}$ & $\begin{array}{c}\text { Nucleotide diversity } \\
(\boldsymbol{\pi})\end{array}$ & $\begin{array}{c}\text { Conserved } \\
\text { region }(\mathbf{C})\end{array}$ \\
\cline { 2 - 3 } & Population Haplotype & $0.457 \pm 0.037$ & & $0.00089 \pm 0.00008$ & 0.989 \\
COI & $0.001 \pm 0.0010 .003 \pm 0.002$ & & $0.405 \pm 0.058$ & $0.00076 \pm 0.00012$ & 0.995 \\
\hline D-loop & $0.001 \pm 0.0010 .003 \pm 0.001$ & & &
\end{tabular}

Table 3. Haplotypes data of Batagur borneoensis in Ujung Aceh Tamiang's population (Aceh, Indonesia) revealed based on COI and D-loop

\begin{tabular}{|c|c|c|c|c|c|c|c|}
\hline \multirow{2}{*}{ Nucleotide position } & \multicolumn{3}{|c|}{ COI } & \multicolumn{4}{|c|}{ D-loop } \\
\hline & \multicolumn{3}{|c|}{ nucleotide } & \multicolumn{4}{|c|}{ nucleotide } \\
\hline 1 & $\mathrm{~A}$ & $\mathrm{C}$ & $\mathrm{A}$ & - & - & - & - \\
\hline 2 & A & A & $\mathrm{C}$ & - & - & - & - \\
\hline 412 & - & - & - & A & $\mathrm{G}$ & A & A \\
\hline 482 & - & - & - & $\mathrm{G}$ & $\mathrm{G}$ & $\mathrm{G}$ & A \\
\hline 575 & - & - & - & A & A & $\mathrm{T}$ & A \\
\hline Haplotypes & AA & $\mathrm{CA}$ & $\mathrm{AC}$ & AGA & GGA & AGT & AAA \\
\hline No. of individuals in each haplotype & 29 & 60 & 1 & 68 & 14 & 4 & 4 \\
\hline
\end{tabular}

\section{Phylogenetic analysis}

The topology of ML and NJ trees of haplotypes of Batagur borneoensis in Ujung Aceh Tamiang's population based on COI presented in Figure 2, meanwhile based on D-loop region presented in Figure 3. In COI, both ML and NJ showed that three different haplotypes were group in 2 groups. As well as COI, phylogeny trees based on D-loop also show high levels of nucleotide similarity among populations with very low genetic distances. The trees divided into two major groups with a limited branching because almost all individuals have the same nucleotide. These groups separation is not very clear or unstable, because the bootstrap values were very low.

There were a total of three haplotypes on $\mathrm{COI}$ and four haplotypes on $D$-loop region with $\mathrm{n}=90$. Haplotype sequences were very similar to each other and were on average only $0.3 \%$ divergent (range $0.2 \%-0.4 \%$, Kimura-2 parameter distance) on COI. As well as COI, haplotype sequences using $D$-loop were on average $0.3 \%$ ((range $0.2 \%-0.4 \%$, Kimura- 2 parameter distance). This result is lower than the result from 30 individuals of $B$. borneoensis were a total number of 13 haplotypes from Malaysia. Haplotype sequences were very similar to each other and were on average only $0.5 \%$ divergent (range $0.2 \%-1.3 \%$, Kimura-2 parameter distance) (Meredith, 2010). The value of Tajima's test was -0.307 and Fu and Li's test was 0.0497, which means that the genetic diversity in the population is not significant.

In our study, from 30 nests which each nest represented by 3 individuals. Based on haplotype distribution showed that in COI there were nine nests which contain all juveniles with same haplotype (1 nest has haplotype AA and 8 nests have haplotype CA), meanwhile, 21 nests have different haplotype (in this case has 2 haplotypes in each nest). In the control region, there were 20 nests has same haplotype which dominated by haplotype AGA (17 nests), GGA ( 2 nests), and AAA (1 nest), and 10 other nest has different haplotype.

The percentage of similarity on haplotype between nests was reached $66.7 \%$ based on D-loop and $30 \%$ based on COI. It is shown that the population of B. borneoensis on the Ujung Aceh Tamiang coast in a critical condition. The nucleotide diversity $(\pi)$ is very low (Table 2 ) with average number of nucleotide differences $(\mathrm{k})=0.4716$ in COI and 0.4374 in $D$-loop. This low nucleotide diversity suggested a population bottleneck in the B. borneoensis, possibly caused by the hunting for consumption, certain retails, habitat lost, and highest in breeding level on the restriction habitat. Based on these genes region, seen that the diversity of individuals was higher in D-loop, from ten different nests showed have three individuals with different haplotypes, even though the total number of nests that were higher monomorphic. In contrast, the COI marker shows that nests with different haplotypes have higher percentages, but individual diversity is lower in the same nest, which only has 2 haplotypes in each nest. Control region is a hypervariable region with high base substitution so that it is possible for individual diversity to be identified higher. D-loop, giving confidence to this condition, because in vertebrates this region well known as hypervariable or has a high base mutation both substitution, deletion, or base insertion so it is widely used to see the level of intra-species diversity (Saccone et al. 1987). Dloop revealed very little variation (Tikochinski et al. 2012).

It also seems, that probably nest with same haplotype came from same male but it needs to be proven. Therefore, genetic fingerprinting may also important to be conducted. From this method, the sex ratios of breeding adults, mating patterns such as level of multiple paternity and male reproductive will be known (Komoroske et al. 2017). In $B$. borneoensis this information really doesn't know as well as on other Sundaland freshwater turtles. Multiple paternity was recorded on Podocnemis erythrocephala from Brazil (Fantin et al. 2010), Elseya albagula from Australia (Todd 
et al. 2013), and captivity population of Testudo hermanni boettgeri (Farke et al. 2015). Most information multiple paternity limited on sea turtle such as in hawksbills (Phillips et al. 2013), loggerheads (Sari et al. 2017), leatherbacks (Stewart and Dutton 2011), olive ridleys (Jensen et al. 2006) and green turtle (Fitzsimmons 1998).

Referring to the results of the above research it is necessary to improve conservation management by selecting new brooders or new blood to increase population diversity. Bottleneck population indicates high levels of inbreeding so new blood is needed. Although B. borneoesis populations in Indonesia have historically spread across the east coast of Sumatra Island and western Kalimantan, it is currently thought that the remaining populations in Sumatra are only found on the coast of Langkat Regency and the Aceh Tamiang mangrove forest area (Guntoro, 2012). Thus it is necessary to know the quality of each population that is spread as a whole on the islands of Sumatra and Kalimantan which can be used as new blood. In 1985, B. borneoensis was reported to be very abundant in five rivers in Peninsular Malaysia with the Setiu River supporting the largest population (Sharma, 1997), but today all populations are declining precipitously (Norkarmila, 2009). This means that the decline in the quality of the population of $B$. borneoensis is almost everywhere in Indonesia and Malaysia.
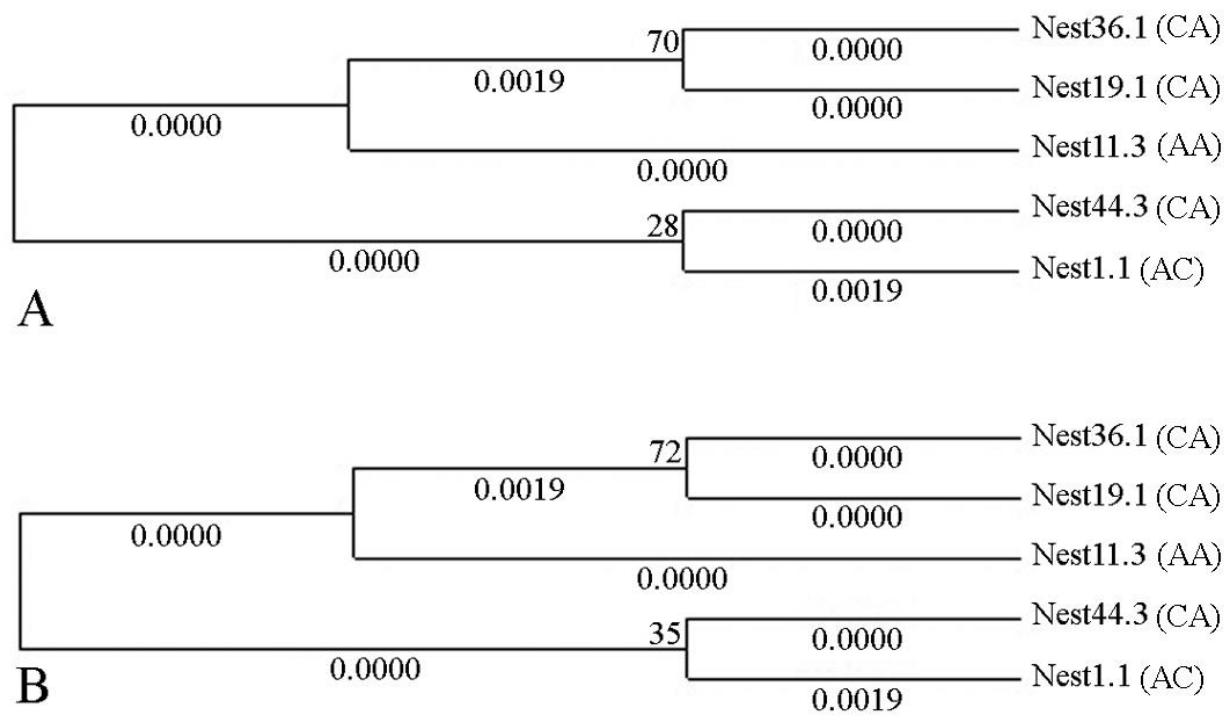

Figure 2. Maximum-likelihood (A) and Neighbor-joining (B) dendrograms of three haplotypes of Batagur borneoensis in Ujung Aceh Tamiang's population based on COI. Nest36.1 - individual 1 from nest 36. Haplotypes in parenthesis

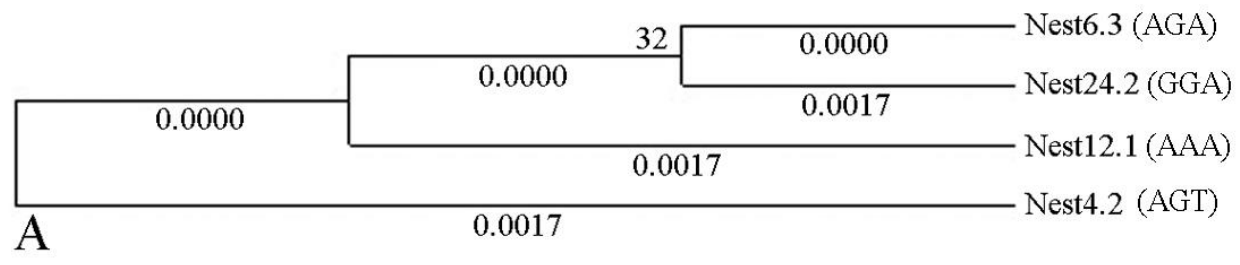

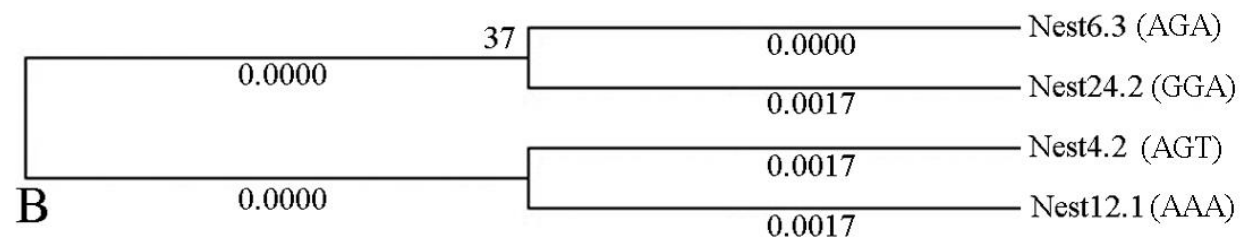

Figure 3. Maximum-likelihood (A) and Neighbor-joining (B) dendrograms of four haplotypes of Batagur borneoensis in Ujung Aceh Tamiang's population based on control region D-loop. Nest6.3 - individual 3 from nest 6 . Haplotypes in parenthesis 
A recent study by Duli (2009) on comparison of genetic variation at mitochondrial cytochrome $\mathrm{b}$ and $D$-loop for female B. borneoensis and its congener B. baska on the east and west coast of Peninsular Malaysia shown the significant genetic structure between east and west coast for $B$. baska but not for B. borneoensis. Since lacks information on dispersal patterns of $B$. borneoensis, we agree to Hawkins (2010) that posibillity of the adult has capable of long-distance dispersal resulting in low population differentiation. Dunson and Moll (1980) report that when hatching leaves the beach they can withstand seawater for up to weeks, Hawkins (2010) was hypothesised that hatched may dispersed by ocean current.

Our finding in low genetic variability may relevant results of Spitzweg et al. (2018) that studied on captive breeding project of $B$. baska in Bangladesh and Australia. They conclude that given the long life expectancy of turtles, this situation suggests that the wild population had experienced a severe decline for long ago. The few survivors are largely related at the level of half-sibs (or first cousins, aunts/uncles-nices/nephews, or grandparentsgrandchildren). They propose conservation strategy with preserved the present genetic diversity to the greatest extent possible. The reproduction of closely related terrapins has to be avoided. They also suggested implementing the selective breeding and some mating combinations be avoided.

Based on those situations above, we suggested that further study such as more exploration to find new wild populations, genetic study across wild populations should be done to reveal genetic variability and genetic structure, and genetic fingerprinting which important to decide the conservation strategy. At this time, for Aceh Tamiang's population, the ranching conservation program should be maintained at least to keep successful hatchling from hunters and natural predators both during eggs and hatching.

\section{ACKNOWLEDGEMENTS}

We are grateful to the reviewers for their help in greatly improve our manuscript. We thank the Aceh's Natural Resources Conservation Agency (Balai Konservasi Sumberdaya Alam Provinsi Aceh/BKSDA) and Local Government of Aceh Tamiang, Aceh Province, Indonesia for the permit and facilities in the Batagur borneoensis Conservation project by Satucita Lestari Indonesia in Aceh Tamiang. PT Pertamina EP Rantau Field for funded the laboratory work. The authors (JG, W, and AR) have an equal contribution in this work.

\section{REFERENCES}

Allendorf FW, Hohenlohe PA, Luikart G. 2010. Genomics and the future of conservation genetics. Nat Rev Genetic 11: 697-709.

Alvarez MIG, Gordillo JML, M'Rabet SM, Ruiz CEZ, Gomez LDO, Vazquez MRB, Rodas LR, Marín AV, Lopez HGV, Weiss LSA.
2019. Genetic diversity and population structure of founders from wildlife conservation management units and wild populations of critically endangered Dermatemys mawii. Global Ecol Conserv 19: e00616. DOI: 10.1016/j.gecco.2019.e00616.

Bhaskar R, Mohindra V. 2018. Variability in DNA COI sequences reveals new haplotypes in freshwater turtles from northern region of India, Mitochondrial DNA Part B. 3 (1): 317-323.

Corlett RT. 2016. Plant diversity in a changing world: Status, trends, and conservation needs. Plant Divers 38: 10-16. DOI: 10.1016/j.pld.2016.01.001

Duli NB. 2009. Morphometric and genetic variability of river terrapin (Batagur baska) and painted terrapin (Batagur borneoensis). [Thesis]. Universiti Sains Malaysia, Pulau Pinang.

Fantin C, Farias IP, Mojel LAS, Hrbek T. 2010. Polyandry in the redheaded river turtle Podocnemis erythrocephala (Testudines; Podocnemididae), in the Brazilian amazon. Genet Mol Res 9: 435440.

Farke CM, Olek K, Gerding WM, Distler C. 2015. Multiple paternity and sperm storage in captive Hermann's tortoises, Testudo hermanni boettgeri determined from amniotic fluid adhering to the eggshell. Mol Cell Probes 29 (4): 254-257.

FitzSimmons NN. 1998. Single paternity of clutches and sperm storage in the promiscous green turtle (Chelonia mydas). Mol Ecol 7: 575-584. DOI: 10.1046/j.1365-294x.1998.00355.x

Guntoro J. 2012. Tracing the footsteps of painted terrapin (Batagur borneoensis) in Aceh Tamiang Regency, Aceh, Indonesia. Preliminary Observation. J Radiata 21 (1): 60-67.

Hawkins ME. 2010. Genetic analysis and captive breeding program for the critically endangered painted terrapin (Batague borneoensis). [Thesis]. Texas Christian University, Texas.

Ihlow F, Ahmadzadeh F, Ghaffari H, Taskavak E, Hartmann T, Etzbauer C, Rodder D. 2014. Assessment of genetic structure, habitat suitability and effectiveness of reserves for future conservation planning of the Euphrates soft-shelled turtle Rafetus euphraticus (Daudin, 1802). Aquat Conserv 24: 831-840.

Ismail NA, Ghani NIA, Pelf-Nyok C, Manaf LA, Jamil NR, Ismail A. 2016. Cross-species microsatellite amplification of River Terrapin (Batagur affinis). Acta Biologica Malaysiana 5 (2\&3): 75-79. DOI: 10.7593/abm/5.2-3.75

Jensen MP, Abreu-Grobois FA, Frydenberg J, Loeschcke V. 2006. Microsatellites provide insight into contrasting mating patterns in arribada vs. non-arribada olive ridley sea turtle rookeries. Mol Ecol 15: 2567-2575. DOI: 10.1111/j.1365-294X.2006.02951.x

Komoroske LM, Jensen MP, Stewart KR, Shamblin BM, Dutton PH. 2017. Advances in the application of genetics in marine turtle biology and conservation. Front Mar Sci 4: 156. DOI: 10.3389/fmars.2017.00156

Kumar S, Stecher G, Li M, Knyaz C, Tamura K. 2018. MEGA X: Molecular evolutionary genetics analysis across computing platforms. Mol Biol Evol 35: 1547-1549.

Lalitha R, Chandavar VR. 2018. Intraspecific variations in Cyt b and $D$ loop sequences of Testudine species, Lissemys punctata from south Karnataka. J Adv Res 9: 87-85.

Librado P, Rozas J. 2009. DnaSP v5: A Software for comprehensive analysis of DNA polymorphism data. Bioinformatics 25: 1451-1452.

Meredith EH. 2010. Genetic analysis of the captive breeding program for the critically endangered painted terrapin, Batagur borneoensis. [Thesis]. Graduate Faculty of the College of Science and Engineering Texas Christian University, Texas.

Mittermeier RA, van Dijk PP, Rhodin GJ, Nash SD. 2015. Turtle hotspots: An analysis of occurrence of tortoise and freshwater turtles in biodiversity hotspots, high-biodiversity wilderness areas, and turtle priority areas. Chelonian Conserv Biol 4 (1): 2-10.

Moll D, Moll EO. 2004. The Ecology, Exploitation, and Conservation of River Turtles. Oxford University Press, New York.

Nezhad SRK, Modheji E, Zolgharnein H. 2013. Polymorphism analysis of mitochondrial DNA control region of hawksbill turtles (Eretmochelys imbricata) in the Persian Gulf. J Fish Aquat Sci 7 (5): 339-345.

Norkarmila BD. 2009. Morphometric and genetic variability of river terrapin, (Batagur baska) and painted terrapin, (Batagur borneoensis). [Thesis]. University Sains Malaysia, Penang, Malaysia.

Permenhut 106/MENLHK/SETJEN/KUM.1/2018 tentang Perubahan Kedua Atas Peraturan Menteri Lingkungan Hidup Dan Kehutanan 
Nomor P.20/MENLHK/SETJEN/KUM.6/2018 tentang Jenis Tumbuhan Dan Satwa Yang Dilindungi. [Indonesian]

Phillips KP, Jorgensen TH, Jolliffe KG, Jolliffe SM, Henwood J, Richardson DS. 2013. Reconstructing paternal genotypes to infer patterns of sperm storage and sexual selection in the hawksbill turtle. Mol Ecol 22: 2301-2312. DOI: 10.1111/mec.12235

Pierson JC, Coates DJ, Oostermeijer JGB, Beissinger SR, Bragg JG, Sunnucks P, Schumaker NH, Young AG. 2016. Genetic factors in threatened species recovery plans on three continents. Front Ecol Env 14 (8): 433-440.

Rhodin AGJ, Walde AD, Horne BD, van Dijk PP, Blanck T, Hudson R. 2011. Turtles in Trouble: The World's 25+ Most Endangered Tortoises and Freshwater Turtles-2011. IUCN SSC Tortoise and Freshwater Turtle Specialist Group, Turtle Conservation Fund, Turtle Survival Alliance, Turtle Conservancy, Chelonian Research Foundation, Conservation International, Wildlife Conservation Society, and San Diego Zoo Global. Lunenburg, MA.

Saccone C, Attimonelli M, Sbisa E. 1987. Structural elements highly preserved during the evolution of the D-loop containing region in vertebrate mitochondrial DNA. J Mol Evol 26: 205-211.

Sari F, Koseler A, Kaska Y. 2017. First observation of multiple paternity in loggerhead sea turtles, Caretta caretta, nesting on Dalyan Beach, Turkey. J Exp Mar Bio Ecol 488: 60-71.

Spitzweg C, Praschag P, DiRuzzo S, Fritz U. 2018. Conservation genetics of the northern river terrapin (Batagur baska) breeding project using a microsatellite marker system. Salamandra 54 (1): 63-70.
Stanford CB, Rhodin AG, van Dijk PP, Horse PD, Blanck T, Goode EV, Hudson R, Mittermeier RA, Currylow A, Eisenberg C, Frankel M, Georges A, Gibbons PM, Juvik JO, Kuchling G, Luisell L, Shi H, Singh S, Walde A. 2018. Turtle in Trouble: The World's 25 + Most Endangered Tortoise and Freshwater Turtles-2018. Turtle Conservation Coalition, IUCN SSC Tortoise and Freshwater Turtle Specialist Group, Turtle Conservancy, Turtle Survival Alliance, Turtle Conservation Fund, Conservation International, Chelonian Research Foundation, Conservation International, Wildlife Conservation Society, and Global Wildlife Conservation. Ojai, CA.

Stewart KR, Dutton PH. 2011. Paternal genotype reconstruction reveals multiple paternity and sex ratios in a breeding population of leatherback turtles (Dermochelys coriacea). Conserv Genet 12: 11011113. DOI: $10.1007 / \mathrm{s} 10592-011-0212-2$

Tikochinski Y, Bendelac R, Barash A, Daya A, Levy Y, Friedmann A. 2012. Mitochondrial DNA STR analysis as a tool for studying the green sea turtle (Chelonia mydas) populations: The Mediterranean Sea case study. Mar Genom 6: 17-24.

Todd EV, Blair D, Limpus CJ, Jerry DR. 2013. High incidence of multiple paternity in an Australian snapping turtle (Elseya albagula), Austr J Zool 60: 412-418.

Zhan A, Bailey SA, Heath DD, Macisaac HJ. 2014. Performance comparison of genetic markers for high-throughput sequencing-based biodiversity assessment in complex communities. Mol Ecol Resour 14: 1049-1059. 